\title{
Poging tot ' $n$ herdefinisie van die prediking binne die raamwerk van die Reformatiese teologie
}

\author{
TFJ Dreyer \\ Universiteit van Pretoria
}

\begin{abstract}
An attempt to redefine praeching in terms of Reformational theology
\end{abstract}

In the field of biblical studies and hermeneutics, modern research, in many aspects results in questioning the authority of the Bible as the Word of God. The consequences of these results often undermine preaching as the Word of God. Within the theology of the reformation, preaching is based upon sound exegetical study and expository of the biblical text. Hence scientific exegetical research brings the authority of preaching to a crisis.

This paper is an attempt to redefine preaching in order to incorporate the results of modern research, as well as to conserve the fundamental concept of preaching as the Word of God.

Wie die Predigt Wort Gottes sein oder werden kann ist das Grundproblem der Homiletik (Bohren 1974: 48).

Die verkondiging van die Woord van God is tegelyk die essensie en die eksistensie van die kerk. Dié konstituerende funksies van die prediking vir die kerk blyk ook duidelik uit die belydenisskrifte. Op talle plekke in die Heidelbergse Kategismus kom die belangrikheid van die prediking na vore, byvoorbeeld as vraag 65 stel dat'n mens alleenlik tot geloof kan kom deur die Heilige Gees wat dit in ons harte werk deur die verkondiging van die heilige evangelie. In vraag 83 word die verkondiging van die evangelie en die christelike tug beskryf as die sleutels waarmee die koninkryk van die hemel oop- en toegeslujt word. Die Woordbediening word in vraag 103 
as die konstituerende element van die onderhouding van die rusdag beskryf. Die Nederlandse Geloofsbelydenis ken in art 29 aan die suiwere prediking van die evangelie ' $n$ wesenlike funksie toe, deur die prediking te beskryf as een van die kenmerke van die ware kerk.

Dit blyk dus dat die belydenisskrifte die saak van die prediking, woordbediening, of verkondiging van die evangelie beklemtoon, maar laat dit na om werklik die wese en omvang van die saak eksplisiet te stel. Om hierdie probleemstelling te belig sal daar in die verdere ontwikkeling van die teologiese tradisie na antwoorde gesoek moet word.

\section{PREDIKING IN DIE REFORMATORIESE TEOLOGIE}

Binne die dampkring van die Reformatoriese teologie word daar in verskeie belydenisgeskrifte na die prediking, of verkondiging verwys. 'n Verdere verduideliking van wat presies met prediking bedoel word, ontbreek egter. Slegs in die Tweede Switserse Konfessie van 1566, word 'n omskrywing van prediking gegee. As peiler van die 'amptelike' beskouing van prediking in die Reformatoriese teologie, word genoemde Switserse Konfessie as eksponent geneem. Die opvatting van Luther en Calvyn kan ook in die verband kortliks gestel word, as refleksie van die Reformatoriese denke oor die prediking.

\subsection{Die Tweede Switserse Konfessie 1566}

Hoofstuk 1 van hierdie konfessie handel oor De Scriptura Sancta, Vero Dei Verbo (Schaff 1919: 237). Nadat daar inleidend gehandel word oor die Heilige Skrif as kanon vir geloof en lewe, word daartoe oorgegaan om die prediking te verduidelik as die Woord van God wat spreek.

Proinde cum hodie hoc Dei verbum per praedicatores legitime vocatus annunciatur in Ecclesia, credimus ipsum Dei verbum annunciari et a fidelibus recipi, neque aliud Dei verbum vel fingendum, vel coelitus esse exspectandum: atque in praesenti spectandum esse ipsum verbum, quod annunciatur, non annunciantem ministrum, qui, etsi sit malus et peccator, verum tamen et bonum manet nihil ominus verbum Dei (Schaff 1919: 237).

Vryvertaal kan hierdie stelling as volg weergegee word (Leith 1973: 133): 
Wanneer die Woord van God in die kerk gepreek word, deur predikers wat wettig geroep is, glo ons dat die ware Woord van God verkondig is en so deur die gelowiges ontvang word. Geen ander Woord van God kan versin, of uit die hemel verwag word nie. Die Woord self, wat nou gepreek word, moet geag word, nie die prediker wat preek nie, wat alhoewel hy 'n swakke sondaar is, nogtans aan die Woord van God in waarheid en getrouheid vashou.

Die problematiek wat in hierdie uitspraak opgesluit le is die vraag na die verband, oorgang of metamorfose van mensewoord na Woord van God. Hierdie vraagstelling word in 'n bepaalde mate beantwoord as die stelling rakende die prediking gelees word teen die breër konteks van die belydenis. Voorafgaande aan die stelling van die prediking as Woord van God, word die Heilige Skrif as die ware Woord van God bespreek. Beide Ou en Nuwe Testament word beskou as die geinspireerde kanon wat geld as die enigste norm vir prediking, kerkregering en die lewe van die geloof. 'n Meganiese skrifinspirasie le ten grondslag van hierdie skrifbeskouing, as daar uitdruklik gestel word dat niks uit hierdie Skrif weggeneem of bygevoeg mag word nie (Schaff 1919: 237).

Die uitspraak dat die prediking Woord van God is, berus dus enersyds daarop dat die Heilige Skrif Woord van God is. Wanneer die Heilige Skrif gepreek word, is die prediking daarom ook Woord van God. Hierdie Skrifbeskouing (vanuit die perspektief van 'n meganiese skrifinspirasie) is ook die siening soos weerspieël in die Nederlandse Geloofsbelydenis (Artikel 3-7), en dit vorm die basis vir die uitspraak dat die prediking daarom ook Woord van God is.

Hierdie Reformatoriese binding en gelykskakeling van Skrif en prediking vra om nadere kwalifisering. Indien prediking die blote repetering of resitering van 'n skrifteks is, skep dit geen probleem nie, maar omdat prediking die elemente van uitleg, verklaring en toepassing insluit, is dit dus meer as die skrifteks en juis daarin is die probleem geleë. Is hierdie 'meer as' die skrifteks ook nog Woord van God? Pieterse (1985: 11) kwalifiseer hierdie reformatoriese beginsel as volg:

Die Woord van God kan in die prediking gehoor word in soverre dit die Skrifwoord lewend deur die Heilige Gees verkondig. In die mate waarin die preekteks in die preek funksioneer en tot spreke kom, in daardie mate kan die Woord van God daarin gehoor word.

Die prediking as Woord van God moet dus die toets kan deurstaan of dit getrou is aan die Skrif. Die bybelboodskap as geheel, ook soos dit neerslag gevind het in die 
belydenisskrifte, kom ter sprake by hierdie toetsing. Die pretensie dat die prediking Woord van God is, berus dus op die premisse dat dit skrifgetrou en -gebonde sal wees.

Andersyds word die prediking as Woord van God moontlik gemaak deur die werking van die Heilige Gees. Die Tweede Switserse Konfessie sluit die stelling oor die prediking af met die beredenering van die illuminasie deur die Heilige Gees. Deur die innerlike verligting van die Heilige Gees kan God in sy vrye wil ook mense sonder die prediking tot geloof bring. Die normale wyse waarop die kerk in gehoorsaamheid aan God se Woord mense tot geloof kan bring is egter deur die uitwendige prediking, wat deur die innerlike verligting van die Gees deur mense as Woord van God gehoor en geglo word (Schaff 1919: 238).

Die Reformatoriese uitspraak dat die prediking van die Woord van God self Woord van God is, word dus onderbou deur die feit dat die Heilige Skrif Woord van God is en dat die verligting van die Heilige Gees in die harte van mense by hulle die belydenis bring dat die prediking Woord van God is. Hierdie standpunt motiveer dan ook die gesag en sentraliteit van die prediking in die reformatoriese kerk.

\subsection{Calvyn}

Calvyn het soos die ander Hervormers die prediking as die belangrikste taak van die kerk gesien (Parker 1975: 89). Hy noem die prediking die 'hoofsenuwee' en die 'siel' van die kerk (Inst 4.2.7 soos vertaal deur Sizoo 1956: 49). Tog is dit vreemd dat hy nie 'n aparte hoofstuk van sy Institusies aan die prediking gewy het nie. Sy siening van die prediking le verspreid in sy opus magnum (Van der Walt 1987: 1-15).

'n Basiese konsep in die denke van Calvyn is dat prediking nie bloot ' $n$ menslike daad is nie, maar 'n menslike daad wat deur God in beweging gebring word.

God is the author or instigator of preaching ... Christ is therefore the real Preacher (Inst 2.15.2), but in His wisdom He decided to appoint humans as ministers of His Word ... in giving this command to the apostles, Christ in fact gave it to His Church of all times, with the result that the gospel, by whomever it may be preached, is nothing else than the Word of God Himself (Van der Walt 1987: 2).

Die gesag van die prediking lê nie primêr in die menslike prediker nie, maar in die Woord wat hy verkondig (Inst 4.11.1 Sizoo 1956: 236). Vanuit hierdie gesag van die prediking word dit dan ook een van die sleutels van die koninkryk van die hemel 
(Inst 3.4.14), asook een van die kenmerke van die ware kerk (Inst 4.2.4; 4.1.10).

Die inhoud van die prediking is die hele Woord van God. Daarom het hy in sy eie prediking veral die metode van boekprediking gevolg (Van der Walt 1987: 4). Van der Walt poneer dat alhoewel Calvyn die hele Skrif as inhoud van die prediking sien, dit tog uit die Institusie duidelik word, '... where Calvin wanted the main accents in preaching to be laid' (1987: 4).

Op grond van die versoeningswerk van Jesus Christus moet die mens in die prediking opgeroep word tot bekering en geloof (Inst 3.2.2.10). '... he must direct all his attention to repentance over the faults of his former life, and turn his steps towards the right path (Van der Walt 1987: 4).

As vereiste en voorwaarde vir die prediker le Calvyn veral klem op die suiwer leer en 'n vroom lewe (Inst 4.3.12). Die uiterlike roeping van die gemeente is die enigste weg waarlangs iemand werklik bedienaar van die Woord kan word (Inst 4.3.10). Waar so 'n geroepe bedienaar van die Woord die Woord van God aan die gemeente verkondig, is die resultaat dat die Heilige Gees wat die weg vir die prediking na die hart van die hoorder voorberei, mense tot geloof bring. 'As Calvin points out 'listening' is very often in the Bible synonymous with 'believing" (Van der Walt 1987: 10).

By Calvyn vind ons dus ook die konstituerende elemente van die prediking, dat dit Woord van God is, omdat die prediker as geroepene die Woord verkondig wat deur die werking van die Gees mense tot geloof bring. Vir Calvyn het die prediking die funksie van heilsbemiddeling (Brienen 1974: 294). Hy stel dit in sy Institusie (1.11.7) as volg: 'Paulus getuigt (Gal 3:1), dat Christus door de ware prediking van het evangelie afgeschilderd wordt, en in zekere zin voor onze ogen gekruisigd word' (Sizoo 1956: 81). H Jonker toon tereg aan dat by Calvyn die prediking as Woordverkondiging teenoor die roomse sakramentalisme as 'n heilsbemiddelende gebeure gesien word (Jonker sa: 120 ). Die korrelasie van die prediking en die realisering van die heil word deur Calvyn gelè.

\subsection{Luther}

Die denke van Luther val in breë trekke saam met die van Calvyn, alhoewel daar kleiner aksentverskille bestaan. By Luther word die prediking net soos die Heilige Skrif, aangedui as Woord van God (Jonker s a: 120). In die prediking as verkondiging van die evangelie sien Luther die teenwoordigheid van die lewende Christus met sy heil (Bakker 1964: 68). By Luther word die werking van die Heilige Gees nou verbind met die bediening van die Woord. Woord en Gees is onafskeidbaar soos stem en asem. Jonker (s a: 121) formuleer dit soos volg: 
Voor Luther is het een grondregel van de kerk, dat zij in de prediking het in de Bijbel gegeven spreken van God present moet maken voor de mensen. Niet zozeer de bijbel als boek, maar de Bijbel als Wodrd plaats hij in het middelpunt ... Toch is het noch geen christelijkeprediking, wanneer louter historisch over Jesus word gesproken. De preek moet gebeuren om de geschiedenis van Jezus zodanig te brengen, dat zij ons tot gerechtigheid en heil dient (Bijlsma 1977: 24).

Die aksentverskille tussen Luther en Calvyn se siening oor die prediking sentreer rondom die verband tussen die Heilige Gees en die Woord. By Luther gaan dit om die verlossing in radikale sin van deur die woord (per verbo) terwyl dit by Calvyn gaan om die verlossing saam met die woord (cum verbo). Teenoor Luther wat die werking van die Heilige Gees so sterk verbind aan die middelike verkondiging, het Calvyn ook meer 'n oog vir die soewereiniteit van die Heilige Gees (De Klerk 1977: 36). Calvyn is ook in sy skrifbeskouing minder Christosentries as Luther (Jonker sa: 120).

Nieteenstaande genoemde aksentverskille word dieselfde grondtoon aangetref naamlik dat die prediking in sy wese Woord van God is.

\subsection{Samevatting}

As die Reformatoriese siening oor die wese van die prediking in 'n neutedop saamgevat word, is daar die een groot saak wat telkens na vore kom naamlik dat die prediking self die Woord van God is. Hierdie stelling word onderbou deur ' $n$ aantal voorvereistes:

- Die Heilige Skrif is die Woord van God. As die prediking dus skrifgebonde en skrifgetrou is, is die prediking ook Woord van God.

- Die Heilige Gees is die inspirator van die Skrif en die Heilige Gees verlig ook die harte van die hoorders om die woord van die prediking te hoor en te glo as Woord van God.

- Daar kan slegs sprake wees van die bediening van die Woord van God as die prediker ook wettig deur die gemeente geroep is.

Hierdie wesenskenmerke van en voorvereistes vir die prediking het binne die Reformatoriese kerke in die praktyk van die prediking die volgende karakteristieke eienskappe aan die prediking toegeken. 
- Reformatoriese prediking is skrifgetrou. Die skrifteks moet so noukeurig as moontlik uitgele en verklaar word. Wetenskaplike eksegese word 'n voorvereiste vir die prediking. Waar die prediking 'n terugkeer tot die Woord van God was is die Heilige Skrif volgens die analitiese metode vers vir vers verklaar met 'n duidelike toepassing (De Klerk 1977: 37). Suiwer eksegese en die korrekte oorbring van die teks na die gemeente, was die waarborg dat die prediking Woord van God sal wees.

- Prediking is Christusprediking. 'Jesus Christus is self die oorspronklike gestalte van die kanoniese heilswaarheid - nie as 'n metafisiese prinsiep nie, maar as die lewende Heer wat die mens hede tegemoet tree in sy lewende Woord' (Pieterse 1988: 3).

- Prediking is gebind aan die kerklike belydenis. Omdat prediking skrifgetrou moet wees en die belydenis die neerslag is van die kerklike verstaan van die Skrif, kan en mag nie buite die grense van die belydenis beweeg nie (Dreyer 1985: 378$386)$.

\section{ENKELE MEER RESENTE DEFINISIES VAN DIE PREDIKING}

Hierdie basiese beskouing van die prediking het in die verdere historiese ontwikkeling van die Reformatoriese teologie die uitgangspunt gevorm. Tog is daar ook weer telkens nuwe en ander aksente wat gelê word. Enkele definisies sal die nuansverskille voldoende belig.

\subsection{T Hoekstra}

Hoekstra word in sommige kringe beskou as die grondlegger van die gereformeerde Homiletiek (De Klerk 1977: 13). Hoekstra (sa: 157) definieer die prediking as volg:

Het wezen van de bediening des Woords bestaat hierin, dat zij is de verklaring en de toepassing van het Woord Gods, geopenbaard in de Heilige Schrift.

Hierdie definisie van Hoekstra is die mees gangbare in gereformeerde kringe, omdat die aksent hier sterk lê op die uitleg en verklaring van die teks. In Reformatoriese lyn is die teksgetrouheid die waarborg dat die prediking Woord van God sal wees. 


\section{$2.2 \mathrm{G}$ van der Leeuw}

Van der Leeuw volg Hoekstra in sy definisie, maar lê weer meer klem op die profetiese karakter van die prediking:

De prediking des Woords is in de eredienst enerzijds leerrede, die de Schrift uilegt in verband met het dogma der Kerk; anderzijds verkondiging, kerugma profetie (Van der Leeuw sa: 184).

Hier voel 'n mens al die spanning aan dat die eksegese en uitleg van die Skrif alleen, nog nie die prediking tot Woord van God maak nie. Die profetiese aksent, die kerugma word sterker beklemtoon.

\subsection{KH Miskotte}

By Miskotte het die pendulum deurgeswaai na die ander kant:

... de preek is in wezen kerugma; wat er gezegd wordt op grond van de exegese is een tweede, de eerste vraag is, of het een preek is, die vanwege God iets zegt tot iemand, met een zekerheid en een gezag als aan Gods eigen spreken toekomt (Miskotte 1948: 226).

Hy wil dit duidelik stel dat eksegese en uitleg van die Skrif nie 'n doel op sigself is nie, maar ten dienste is aan die uiteindelike spreke van God self.

\section{$2.4 \mathrm{~K}$ Barth}

Barth gee 'n tweeledige definisie van prediking om die probleem van die verhouding van mensewoord enersyds en Godswoord andersyds te ondervang. Die een is ' $n$ definisie van Bo na onder:

Die predigt ist Gottes Wort, gesprochen von ihm selbst unter Inanspruchname des Dienstes der in freier Rede stättfindenden, Menschen der Gegenwart omgehenden Erklärung eines biblischen Textes durch einem in der ihrem Auftrag gehorsamen Kirche dazu Berufenen (Barth 1966: 30).

Die ander is 'n definisie van onder na Bo: 
Die Predigt ist der der Kirche befohlene Versuch, dem Worte Gottes selbst durch einen dazu Berufenen so zu dienen, dass ein biblischer Text Menschen der Gegenwart als gerade sie aangehend in freier Rede erklärt wird als Ankundigung dessen, was sie von Gott selbst zu hören haben (Barth 1966: 30).

Van God se kant af is die prediking God se Woord wat gespreek word deur die diens van 'n mens wat daartoe geroep is. Van die mens se kant af bly prediking 'n 'versuch', 'n poging om aan te kondig wat hy van God gehoor het. Hierdie dialektiese spanning in die prediking vind sy oplossing in die eenheid van God en mens in Jesus Christus (Barth 1966: 31). Prediking is vir Barth meer as eksegese of 'n voorlesing van die Skrif. '... sondern er sagt vielmehr das von ihm gehörte Schriftwort als sein eigenes, selbständiges Wort' (Barth 1966: 31). Hy verkies ook die begrip aankondiging eerder as verkondiging as aanduiding van die prediking. Aankondiging beklemtoon die feit dat die prediker slegs maar kan aankondig wat God wil sê.

\subsection{Samevatting}

Hierdie meer resente defmisies wil nog steeds in lyn met die Reformatoriese denke uitdrukking gee aan die feit dat prediking Woord van God is. By Hoekstra word dit gevind in getroue eksegese en uitleg. In die ander genoemde definisies word daar telkens gepoog om te beklemtoon dat getroue eksegese en uitleg alleen nie die waarborg is van die spreke van God nie. Prediking is kerugma, profetiese aankondiging wat van Godsweë sê wat hy van God gehoor het.

\section{DIE HEDENDAAGSE VERLEENTHEID VAN DIE PREDIKING}

De Wet maak die stelling dat in kerkordelike dokumente weinig bepalings met betrekking tot die prediking in die kerk te vinde is en dat die bepalings wat wel gevind word, eintlik net die praktyk van die prediking raak.

Hierdie gebrek aan amptelike omskrywings of nadere bepalings van wat die prediking eintlik is of behoort te wees, laat onwillekeurig die indruk, dat wat die kerk altans betref, die prediking so 'n uitgemaakte en duidelike saak is, dat nadere bepaling vir kerklike doeleindes onnodig is (De Wet 1976: 107). 
Waarskynlik was hierdie stelling van De Wet vir 'n lang tyd in die geskiedenis van die kerk waar. Ons het aangetoon dat Reformatories gesien prediking Woord van God is, omdat die Bybel Woord van God is. Daarom was dit vir die kerk nie nodig om veel meer te sê as dat prediking uitleg en toepassing van die Skrif is nie. Die saak van die prediking raak egter problematies die oomblik wanneer die gesag van die Skrif as Woord van God bevraagteken word. As die skrifgesag in gedrang kom, verval die reformatoriese premisse waarop die prediking as Woord van God enersyds berus.

Die vraag na die skrifgesag is al 'n ou vraagstuk in die teologie, wat veral deur die historiese kritiek aan die orde gestel is, maar in die jongste tyd as gevolg van nuwere eksegetiese metodes skerp onder die soeklig val. In plaas van die tradisionele objektiewe gesag van die Skrif, beskryf die sinodale rapport van die GKN, die gesag van die Skrif in terme van 'n relasionele waarheidsbegrip (Geyser 1985: 119-129). Die saak word verder geproblematiseer deur die vraagstuk van die sogenaamde 'kanon in die kanon'. Pelser sê oor hierdie probleem:

Almal sal seker saamstem dat willekeur nie die antwoord kan wees nie. Aan die ander kant lyk dit onvermydelik om die Nuwe Testament steeds bruikbaar vir Christene te laat bly, dat ons nie anders sal kan, as om met 'n 'kanon in die kanon te werk nie (Pelser 1983: 393).

Met hierdie wetenskaplike bevraging van die objektiewe gesag van die Skrif en die worstelinge rondom die 'kanon in die kanon' word dit vir die prediking feitlik onmoontlik om volgens die ou definisie nog spreke van God te bly. Grondige eksegese en uitleg van die Skrif waarborg nie meer die gesagvolle spreke van God in die prediking nie, want dit word nou vir die homileet 'n ope vraag: wat is op grond van die eksegese die Woord van God wat geproklameer kan word? Studente wat in hulle opleiding met hierdie wetenskaplike vraagstelling gekonfronteer word, raak verward oor die uitvoering van hulle profetiese verantwoordelikheid, om in die prediking die Woord van God aan te kondig.

Die oorbring van die kerugma van die skrifteks word geproblematiseer deur die insigte van die nuwere hermeneutiek, wat dit beklemtoon dat ' $n$ historiese teks binne ' $n$ bepaalde verstaanshorison gekommunikeer het. Die oorbring van die kerugma is dus nie ' $n$ reglynige verbinding nie, maar dit moet in 'n nuwe verstaanshorison ingetolk word sodat daar as't ware 'n versmelting van verstaanshorisonne plaasvind. Eers dan het die kerugma van die teks werklik gekommunikeer (Pieterse 1979: 113-116). Dit maak die oorbring van die spreke van God in die historiese teks na die hoorder van vandag uiters gekompliseerd. 
Op grond van die opvatting dat prediking verklaring en toepassing van ' $n$ teks is, word dit vanuit moderne eksegetiese insigte byna 'n onbegonne taak om God tot spreke te bring in die prediking omdat daar in die Bybel 'n diversiteit van teologie is en daar moeilik van 'n teologiese sisteem sprake kan wees (Pelser 1985: 339-350; Smith 1985: 351-363). Prediking kan dan hoogstens die refleksie wees van 'n bepaalde outeur.

Dit is teen hierdie agtergrond wat Bohren praat van die verleentheid van die prediking en die spraakloosheid van die kerk (Bohren 1974: 28-48). Hoe kan God teenswoordig tot spreke gebring word in die prediking? Dit kan nie geskied deur die blote herhaling van 'n historiese teks nie. Indien 'n meganiese skrifinspirasie gehandhaaf word, is dit simplisties gestel maklik om die spreke van God in die prediking te laat hoor, want as die historiese teks oorgebring word, is die spreke van God gewaarborg.

Die Hervormde kerk het hom nog nooit per definisie of verklaring uitgespreek oor wat hy onder prediking verstaan nie. In lyn met die reformatoriese denke was dit egter nog altyd die stilswyende veronderstelling dat prediking Woord van God is. Volgens gereformeerde siening is die ideaal van die prediking as Woord van God, binne die Hervormde Kerk, nagestreef langs die weg van wetenskaplike eksegese, verklaring en toepassing van die teks. Die verskerpte eksegetiese en hermeneutiese metodes en uitsprake rondom skrifgesag, die kanonprobleem, diverse teologieë en die bevraagtekening van 'n sistematiese bybelse teologie, her die prediking laat verarm en verskraal.

As prediking eksegese, verklaring en toepassing van 'n teks is, loop die prediking hom enersyds vas in of 'n parafrase van 'n teksgedeelte of die teologiese refleksie van ' $n$ bybelse outeur. Vanuit hierdie eksegetiese doodloopstraat is die sprong na die verkondiging van die lewende God in die prediking 'n te groot waagstuk. Die ander gevaar is latent by teologiese studente naamlik dat vanweë die problematisering van die eksegese en teologie as deel van die hermeneutiese proses, hierdie deel vermy word en die prediking verval in oppervlakkige moralisme. Beide is 'n verkragting van die wese van die prediking.

Die enigste uitweg uit hierdie impasse en verleentheid van die prediking, is dat daar gesoek sal moet word na 'n nuwe definisie wat reg sal laat geskied aan die reformatoriese siening van die prediking maar wat ook die insigte van die moderne bybelwetenskappe en hermeneutiek kan verdiskonteer.

\section{PREDIKING AS 'N HERMENEUTIESE GEBEURE}

Karl Barth is in 'n sekere sin die oorgangsfiguur op die ontwikkelingsweg van die 
nuwere hermeneutiek, deur sy uitspraak dat die Bybel 'an sich' 'n menslike getuienis van God se openbaring is. Die Bybel is Gods woord 'sofern Gott sie Sein Wort sein lässt, sofern Gott durch sie redet' (Barth 1939: 112). Die Bybel kan God se woord word wanneer die wonder geskied dat God aktueel daardeur in die verkondiging spreek.

Met hierdie Skrifbeskouing wil Barth aandui dat God nie 'n objektiewe fenomeen is, wat voorwerp van wetenskaplike ondersoek gemaak kan word nie, maar dat die 'objek' van die teologie oorspronklik subjek was en weer tot subjek moet word. In die prediking, die hoor en die verstaan van die Woord in die geloof deur die werk van die Gees, word die Skrif tot Woord Gods: die hermeneutiek is dus die wyse waarop die gaping oorbrug word. Die hermeneutiese metode moet dus die subjek-objek teenstelling oorkom (Pieterse 1979: 24).

Volgens Barth moet die Skrif uitgele word in die verwagting om die Woord te hoor. In sy teologiese denke laat hy altyd die klem val op die verstaan van die Skrif vir die hede. Hierdeur het hy die weg oopgemaak vir prediking wat nie net bestaan uit die eksegese en verklaring van 'n teks nie, maar vir 'n omvattende hermeneutiese gebeure waarin die skrifteks weer die lewende Woord van God kan word in die hede.

Volgens Ebeling is die probleem met die verkondiging in die huidige tyd dat dit ' $n$ blote herhaling van die teks is (Ebeling 1959: 246). Die prediking kan nie sy doel bereik met ' $n$ blote repetisie van die teks nie, omdat die prediking nou in 'n ander verstaansituasie die Woord moet bring. Wat in die prediking eintlik moet gebeur, is dat die verkondiging wat eenmaal geskied het, weer opnuut moet geskied (Ebeling 1962: 14-18). Hy yk die begrip 'woordgebeure'. Woord en taal is dinamiese konsepte. Die woord geskied as 'n tydmatige gebeure. Tot die woord behoort dus sowel die situasie van waaruit die woord ontspring as die situasie wat dit ingaan en verander (Pieterse 1979: 42). Om die essensie van die woord en daarom van 'n teksgedeelte te begryp, moet ons nie vra na die inhoud van die woord nie, maar na die uitwerking van die woord, wat die woord tot stand bring, wat deur die woord heen gebeur? Vir die prediking gaan dit dus nie primèr om die vraag wat staan daar nie, maar wat is die intensie, die bedoeling daarvan? Vir Ebeling is die grondstruktuur van die teologie geleè in die beweging van die geskiede verkondiging na geskiedende verkondiging (Pieterse 1979: 38).

Die dinamiese woordgebeure is teologies gesien nie slegs 'n woord en taalgebeure nie, maar ook en veral 'n pneumatologiese gebeure. In die lyn van die 
Reformatoriese teologie, is dit die Heilige Gees wat die 'inspirator' van die Woord is, maar ook die 'illuminator' wat die weg baan sodat die neerslag van 'n historiese verkondiging weer die lewende Woord word, wat hier en nou geskied (Bohren 1974: 82-88).

Die hermeneutiese proses wat afspeel in die preekgebeure is 'n geintegreerde proses wat bestaan uit verskillende komponente. Hierdie komponente of fases kan nie van mekaar losgemaak of geskei word nie, omdat dit van meet af aan almal saam 'n inspraak lewer. Ter wille van die sistematiese uiteensetting is dit tog nodig om die verskillende komponente uit te rafel om 'n geheelbeeld te vorm.

Die Skrif, of vir die doel van die prediking dan die preekteks of perikoop, is die neerslag van 'n 'geskiedeverkondiging' binne 'n historiese konteks. Die teks is deur middel van taalsimbole gekoder binne 'n bepaalde verstaanshorison. Vir die implisiete hoorders of lesers het daardie teks binne hulle verstaanshorison ' $n$ woordgebeure geword, waarin hulle 'n kommunikasie-ervaring met God beleef het.

Vir die prediker wat die Woord moet verkondig gaan dit dus nie primêr om die vraag wat staan daar nie, maar om deur middel van dit wat daar staan deur te dring tot die intensie van die woordgebeure, naamlik wat wil dit wat daar staan laat gebeur? Die eerste fase van die hermeneutiese proses is dus 'n eksegetiese of dekoderingskomponent waarin die prediker wil indring in die taalsimbole en verstaanshorison van die teks. In hierdie eerste fase van eksegetiese dekodering is die eksegeet tegelyk ook homileet wat gelowig mediterend die Woord van God wil verneem. Met meditasie word hier bedoel die gelowige, teologiese worsteling met die teks, met die gebed en verwagting dat God ook deur sy Woord en Gees tot hom sal spreek (Bohren 1974: 347-386 \& Pieterse 1979: 113-116). In hierdie mediterende eksegese vind ' $n$ woordgebeure plaas. Aanvanklik is die homileet die subjek wat die teks as objek bestudeer. In die woordgebeure vind 'n omslag plaas. Die homileet word die objek wat via die teks deur God self aangespreek word. Hy hoor in daardie historiese teks die Woord van God wat hom in 'n totaal nuwe situasie aanspreek. Anders gestel: die prediker kom deur die woordgebeure tot dieselfde kommunikasie-ervaring met God as die oorspronklike lesers of hoorders. Hierdie mediterende eksegese, is nie 'n ongekontroleerde of totaal subjektiewe proses nie, maar die eksegese bly die norm vir die gedagtes wat in die proses loskom (Pieterse 1979: 115).

Die tweede fase in die hermeneutiese proses is om hierdie kommunikasieervaring wat die homileet met die teks en deur die woordgebeure met God gehad het, weer so te enkodeer in simbole wat binne die verstaanshorison van sy gemeente hulle sal lei tot dieselfde kommunikasie-ervaring met God. Dit kan ook 'n fase van 
homiletiese meditering genoem word. Hier kom die hermeneutiese funksie van die teologie ten dienste van die prediking ter sprake. Die teologie het die hermeneutiese funksie om die dinamiese inhoude van die kerugma van die teks in te trek in die teologiese verwysingsraamwerk van die gemeente in hulle konkrete lewenssituasie (Ebeling 1969: 105-117).

Miskien is dit juis hier waar die prediking dikwels in die sand verlore raak. $\mathrm{Al}$ is die eksegese van die teks hoe goed, kommunikeer die teks nog nie met die gemeente voordat die kerugma van die teks so in hulle verstaanshorison gekodeer word dat dit hulle ook tot daardie selfde kommunikasie-ervaring met God lei nie. Waar beide die eksegetiese en homiletiese fases in die hermeneutiese proses so plaasvind, vind daar ook in die prediking 'n woordgebeure plaas waarin die gemeente in 'n total nuwe situasie dieselfde kommunikasie-ervaring met die lewende God beleef, as wat die oorspronklike intensie van die teks was. Dan het daar hermeneuties gesien 'n versmelting van verstaanshorisonne plaasgevind. Hierdie woordgebeure in die historiese situasie sowel as vandag is ' pneumatologiese misterie, omdat die Heilige Gees die inspirator en illumminator is.

Vanuit hierdie hermeneutiese benadering wil die prediking nie net deur middel van die eksegese die gemeente bring tot die verstaan van 'n teks nie, maar deur die woordgebeure hulle lei tot 'n ontmoeting en kommunikasie-ervaring met God. Met die begrip 'kommunikasie-ervaring' word nie noodwendig 'n emosionele ervaring bedoel nie. Kommunikasie-ervaring wil slegs tot uitdrukking bring dat daar kommunikasie plaasgevind het so na as moontlik aan die bedoeling van die sender (Chartier 1981: 62). Daar word beweer dat enige kommunikasiehandeling een of meer van die volgende funksies vervul: ekspressief, kognitief, informatief, emotief, imperatief, esteties, performatief, interpersoonlik, egosentries en faties (Wolmarans 1987: 82). Die kommunikasie-ervaring in die prediking kan daarom ook op een of meer van hierdie vlakke lê.

\section{POGING TOT 'N HERDEFINISIE}

Met die definisie waar die klem hoofsaaklik val op die eksegese, verklaring en toepassing van die teks, staan die prediker teenswoordig in sekere opsigte verleë. Prediking as profetiese spreke, as kerugma, as die Woord van God het op suiwer eksegetiese grond 'n dubieuse onderneming geword. Soos aangetoon word die uitwerking daarvan reeds in die prediking bespeur. Om weer die prediking in lyn te bring met die Reformatoriese bedoeling as Woord van God, sal die Homiletiek as vak en die kerk wat moet verkondig, nie die uitdaging kan vermy om weer te besin oor 'n definisie van prediking nie. Met verdiskontering van nuwere insigte sal daar 
gepoog moet word om prediking so te definieer dat die Reformatoriese bedoeling van die wese van die prediking behoue bly.

Tussen die reëls kan stemme in die verband reeds lankal gehoor word, ook binne die Hervormde Kerk. So se Oberholzer (1974: 130) byvoorbeeld:

Eksegese is die vasstelling van wat die Heilige Skrif sê. Prediking is die verkondiging van die Woord van God volgens die Heilige Skrif. Eksegese is nie prediking nie. Die beweging van die eksegese af na die prediking toe is ' $n$ beweging van die tyd en situasie van die Bybel af na die tyd en situasie toe waarin die prediking geskied.

So het De Wet (1980) in 'n referaat gelewer tydens die predikantevergadering die saak aangeraak onder die tema: 'Is eksegese prediking?' Hierin pleit hy ook daarvoor dat prediking meer is as eksegese en dat daar in die prediking eiesoortige homiletiese vereistes en reëls geld wat nie slegs eksegeties uitgemaak kan word nie.

Pieterse wat in Suid-Afrika in sy publikasies die insigte van die nuwere hermeneutiek vir die prediking diensbaar gemaak het, het ook gepoog om die prediking te herdefinieer. In sy jongste publikasie waarin hy ' $n$ teologiese besinning oor die prediking gee kom dit daarin na vore dat hy sy eerste hoofstuk wy aan die prediking van Jesus Christus.

As Jesus Christus in die middelpunt gestel word, as die prediking 'n prediking van Jesus Christus is, beteken dit die bring van mense tot 'n ontmoeting met Hom as die lewende Heer. Prediking van Jesus Christus is die aanspraak van 'n Persón op die lewens van mense (Pieterse 1988: 1).

Met die vertrekpunt van die prediking wat primêr 'n ontmoeting met die lewende Heer is, beweeg hy dan verder na die begronding van hierdie ontmoetingsgebeure in die Skrifgebondenheid van die prediking. Hier is reeds ' $n$ aksentverskuiwing merkbaar vanaf prediking as eksegese van 'n teks na prediking as 'n ontmoetingsgebeure op grond van die Skrif. Tog ontbreek die deurtrek van die volle konsekwensies van nuut-verworwe insigte.

In 'n definisie van prediking kan die totaliteit van die wese en inhoud van die prediking nooit volledig omskryf word nie. 'n Definisie het hoogstens die funksie om deur middel van enkele kernbegrippe die essensie van die saak weer te gee. Daarom sal daar op grond van die gepoogde herdefinisie enkele verduidelikende opmerkings en terminologiese verklarings gegee word. 
Prediking is 'n pneumatologiese woordgebeure, waarin 'n geroepe bedienaar van die Woord, via 'n kommunikasie-ervaring met 'n skrifteks, die gemeente in hulle konkrete situasie begelei tot 'n ontmoeting met die lewende God.

\section{TERMINOLOGIESE VERKLARING}

\subsection{Pneumatologiese woordgebeure}

Met hierdie terminologiese omskrywing van die prediking is daar gepoog om die hermeneutiese proses in die prediking as 'n woordgebeure te verduidelik. Daardeur is wegbeweeg van die eksegese en verklaring van 'n teksgedeelte, wat maklik 'n bloot formeel-wetenskaplike karakter aan die prediking kan verleen. Hermeneuties gesien sluit die begrip woordgebeure nie die wetenskaplik-eksegetiese voorarbeid vir die prediking uit nie, maar wil dit juis hierdie eksegetiese voorarbeid inkorporeer ten dienste van 'n dinamiese woordgebeure waarin die Woord van God hier en nou 'geskied'.

Die woordgebeure in die prediking is egter nie slegs 'n taalgebeure wat ook in die omgang met ander literêre werke plaasvind nie, dit is gekwalifiseerd 'n pneumatologiese woordgebeure. Die pneumatologiese karakter maak die prediking naas sy wetenskaplike voorarbeid ook 'n misterie van die werking van die Heilige Gees, waarmee die homileet weer telkens gekonfronteer sal word. Hierdeur word uitdrukking gegee aan die Reformatoriese beginsel van die Heilige Gees as 'Inspirator' en 'Illumminator' van die Woord.

Tegelyk wil ons daarmee sê dat prediking 'n geloofsdaad is waarin die homileet ook biddend, gelowig en worstelend weer telkens die wonder van die woordgebeure sal afwag en afsmeek. Dit hou die prediker in sy prediking klein en nederig omdat hy, nieteenstaande al sy wetenskaplike kennis en vaardigheid, nooit oor die Woord kan beskik nie, maar God laat die wonder van die prediking deur sy Gees gebeur waar en wanneer dit Hom behaag.

Hiermee wil ons ook vashou aan die gesag van die prediking as spreke van God. Hierdie gesag is egter nie slegs begrond in 'n skrifgedeelte nie, want as hierdie skrifgedeelte eksegeties bevra word, kom die gesag van die prediking wat daarop gegrond is ook op die spel. Die gesag van die prediking is deur hierdie omskrywing primêr begrond in die woordgebeure, wat 'n soewereine handeling van God is. Waar God deur sy Gees hierdie woordgebeure laat plaasvind het sy Woord gesag selfs soms teen menslike bedenking en wetenskaplike bevraging in. 


\subsection{Geroepe bedienaar van die Woord}

Dit is 'n Reformatoriese beginsel dat prediking as Woord van God ook berus op die voorwaarde van die roeping van die prediker. Daardie inwendige en uitwendige roeping legitimeer die egtheid van sy prediking. Hierdie voorwaarde is ononderhandelbaar. Prediking kan nooit die stokperdjie word van 'n geïnteresseerde bybelwetenskaplike nie. Prediking word gedra deur 'n egte roepingsbewustheid wat neerslag vind in leer en lewe van die prediker. Die uitwendige roeping tot bedienaar van die Woord, vind ook via die gemeente plaas. Dit plaas die prediking altyd binne die ruimte van die gemeente en die kerk. Dit lê op die prediker 'n binding aan die kerk, sy belydenis en sy opsig. In sy teologiese preekarbeid is die prediker gebind aan die grense van die belydenis van die kerk.

\subsection{Via 'n kommunikasie-ervaring met 'n skrifteks}

Die begrip kommunikasie-ervaring is reeds bespreek. Hier wil ons slegs stel dat die teks en die verklaring van wat daar staan nie die doel van die prediking is nie. Wat daar staan het ' $n$ intensie, 'n bedoeling wat dit wil bereik. Die gemeente moet dus deur die eksegese tot hierdie kommunikasie- ervaring of intensie gebring word. 'Via die skrifteks', wil dus beklemtoon dat prediking, slegs prediking volgens Reformatoriese denke is, as dit skrifgebonde en skrifgetrou is. Die skrifteks self is egter nie die hoogste doel nie, dit is slegs die middel wat die gemeente via die kommunikasieervaring tot 'n ontmoeting met God moet begelei. Hier word dit reeds duidelik dat die skopus van die prediking wyer is as die teks. Die skopus van die prediking is God self in die totaliteit van sy openbaring. Dit gee dus aan die prediker die vryheid en die verantwoordelikheid in die prediking, om vanuit die teks wyer te beweeg in die kring van die omvang van die hele Skrif en die belydenis van die kerk. Die prediking wil nie 'n teks aan mense bring nie, maar God self verkondig. Daarom bly dit altyd vir die prediker 'n vraag hoe hierdie bepaalde perspektief van die teks inpas in sy totale verhouding met God.

\subsection{Die gemeente in hulle konkrete situasie}

Prediking is in die eerste instansie gerig op die gemeente, die gelowige kudde van God. Alhoewel daar ook altyd vir die prediking die aksent van geloofstigting sal wees, is die hoofdoel van die prediking versterking en opbou van die geloof tot eer van God (HK Sondag 25, Vraag 65). Die prediking kan daarom ook nie stilstaan by die fondament nie, maar moet verder bou (Heb 6:1-3). Die konkrete situasie van die gemeente is vir die prediking van die allergrootste belang. Die konkrete situasie 
vorm ook in bepaalde opsigte die verstaanshorison waarbinne die woordgebeure moet plaasvind. As die prediking nie hierdie konkrete situasie in sy prediking inkorporeer nie, bly die Woord in die lug hang. Die konkreetheid van die prediking in die situasie van die gemeente beteken nie 'n kondonering van die situasie nie. In sy konkreetheid sal die prediking hom dikwels teenoor die situasie moet afgrens, maar juis daarin lê die konkreetheid binne sy verstaanshorison. Hermeneuties gesien is die moontlikheid tot 'n werklike woordgebeure vir die prediking uiters skraal indien die relevansie van die woordgebeure nie in die konkrete situasie van die gemeente ingetrek word nie.

\subsection{Begelei tot 'n ontmoeting met die lewende God}

Die prediker is slegs die instrument wat God gebruik om mense in die geloof weer telkens na Hom te bring. In die prediking kan hy hoogstens die gemeente begelei. Hy beskik nie oor die mag om hulle te dwing of te manipuleer nie. Net God self kan deur die oormag van sy Woord en Gees mense voor hom in geloof laat buig. Begelei spreek tegelyk ook van 'n mate van outoriteit, leierskap en geroepenheid. Hy kan alleenlik in die prediking begelei omdat hyself reeds die roepstem gehoor het, die weg bewandel het, die ontmoeting beleef het.

Die prediker kom as 'n verwonde op die preekstoel, omdat die Woord hom reeds verwond het. In die prediking sal daar onbewustelik, dikwels nie-verbaal iets deurskemer van sy eie ontmoeting met God.

Die prediker begelei die gemeente tot 'n ontmoeting met die lewende God. Hier word doelbewus gekies vir 'God' in plaas van 'Christus'. Daar is reeds aangetoon dat Luther 'n sterk Christologiese dwang op die prediking selfs van die Ou Testament gelê het, meer as wat die geval by Calvyn was. Calvyn het meer ruimte gelaat vir die soewereiniteit van God. 'n 'Christologiese dwang' in die prediking kom dikwels in botsing met eksegetiese resultate, veral by die prediking van die Ou Testament. As dit in die prediking gaan om 'n ontmoeting met God, dan gaan dit om God in die totaliteit van sy openbaring as drie-enige God, sonder om by voorbaat eksegeties 'n Christologiese dwang toe te pas. Homileties gesien vanuit die verstaanshorisun van 'n nuwe-testamentiese, Christelike gemeente, kan die gelowige God nie anders ken en ontmoet as deur Christus nie. Daarom sal vir die intolking van die kerugma binne 'n Christelike gemeente, die Christologiese perspektief altyd ter sprake kom. Maar uiteindelik het die Christusgebeure die doe! om die mens weer in die regte verhouding met God drie-enig te plaas.

Die ontmoeting met die lewende God is die klimaks van die erediens en die prediking. Waar die pneumatologiese woordgebeure plaasvind, is dit nie meer die 
teks wat verklaar word nie; ook nie die dominee wat oor God preek nie; dit word God self wat in die erediens in die midde van sy gemeente met hulle in ontmoeting tree.

\section{SLOTOPMERKINGS}

Die Hervormde Kerk het doelbewus gekies om sy studente aan 'n universiteit te laat oplei. In dié akademiese milieu word hulle blootgestel aan krities-wetenskaplike denke. Met die ou definisie waarin die eksegese van die teks die alfa en die omega vir die prediking is, het die krities-wetenskaplike denke, die vrymoedigheid tot prediking as gesagvolle spreke van God begin wegkalwe. Vir baie word die versoening tussen krities-wetenskaplike eksegese en profeties-kerugmatiese prediking haas onhanteerbaar. Dit het tweërlei gevolge: in sommige gevalle het die prediking verword tot 'n siellose eksegetiese parafrase van 'n teks; by ander, het dit daartoe gelei dat die eksegetiese voorarbeid en teologiese deurdenking nagelaat word en die prediking laat verval in oppervlakkige moralisme en teologiese bloedarmoede. Albei hierdie weë is vir die lewe van die kerk 'n doodloopstraat.

Dit sal ook vir die kerk 'n teologiese bankrotskap inhou as hy sy teologiese studente weerhou van die blootstelling aan krities-wetenskaplike denke. Daar bly net een moontlikheid oor - die kritiese denke sal op so 'n wyse in die prediking geakkommodeer moet word sonder dat die wese van die prediking daardeur aangetas word. Die poging tot 'n herdefmisie van die prediking was 'n eerste wankelende tree in dié rigting. Die groot winspunt van die herdefinisie is daarin geleë dat die gesagvolle spreke van God nie gedomineer word deur wetenskaplike bevraging nie, maar dat dit uiteindelik die soewereine God is wat hierdie wetenskaplike ondersoek van 'n teks deur sy Gees gebruik en herskep tot sy lewende Woord wat in ons wêreld mense gesagvol aanspreek.

\section{Literatuurverwysings}

BAKKER, JT 1964. Eschatologische prediking by Luther. Kampen: Kok.

BARTH, K 1939. Kirchliche Dogmatik. Bd 1/1. Zürich: Zollikon.

BARTH, K 1966. Homiletik Zürich: EVZ-Verlag.

BIJLSMA, R 1977. De Preek. Kampen: Kok.

BOHREN, R 1974. Predigtlehre. München: Kaiser.

BRIENEN, T 1974. De prediking van de Nadere Reformatie. Amsterdam: Bolland.

CHARTIER, M 1981. Preaching as communication. Nashville: Abingdon.

DE KLERK, JJ 1977. Prediking. Pretoria: NG Kerkboekhandel

DE WET, JI 1976. Die dienskarakter van die prediking. HTS 32, 105-112. 
DE WET, JI 1980. 'Is eksegese prediking? Ongepubliseerde referaat gelewer tydens die predikantevergadering van die Ned Herv Kerk.

DREYER, TFJ 1985. Die dogmatiese binding van die prediking. HTS 41, 378-386.

EBELING, G 1959. Das Wesen des Christlichen Glaubens. Tübingen: Mohr.

EBELING, G 1962. Theologie und Verkündigung. Tübingen: Mohr.

EBELING, G 1969. Wort und Glaube II. Tübingen: Mohr.

GEYSER, PA 1985. Die relasionele waarheidsbegrip en die Christelike lewe - Die sinodale rapport van die GKN. HTS 41, 119-129.

HOEKSTRA, T sa. Gereformeende Homiletiek. Wageningen: Zomer en Keuning.

JONKER, H sa. Actuele Prediking. Nijkerk: Callenbach.

LEITH, JH 1973. Greeds of the Churches. Oxford: Basil Blackwell.

MISKOTTE, KH 1948. Om het levende Woord. S'Gravenhage: Boekencentrum.

OBERHOLZER, JP 1974. Eksegese en prediking. HTS 30, 129-137.

PARKER, THL 1975. John Calvin: a biography. London: Deist.

PELSER, GMM 1985. Die verhouding Bybelse teologie en dogmatiese teologie. HTS 41, 339-350.

PELSER, GMM 1988. Die kanon in die kanon as hermeneuties-teologiese probleem. HTS 44, 388-403.

PIETERSE, HJC 1985. Verwoording en Prediking. Pretoria: NG Kerkboekhandel.

PIETERSE, HJC 1979. Skrifverstaan en Prediking. Pretoria: NG Kerkboekhandel PIETERSE, HJC 1988. Die Woord in die werklikheid. Pretoria: NG Kerkboekhandel.

SCHAFF, P 1919. The Creeds of the Evangelical Protestant Churches. 4th ed. New York: Harpern Brothers.

SIZOO, A 1956. Johannes Calvyn Insitutie. Delft: Meinema

SMITH, DJ 1985. Bybelse teologie-dogmatiese teologie. HTS 41, 351-363.

VAN DER LEEUW, G sa. Liturgiek Callenbach: Nijkerk.

VAN DER WALT, ACP 1987. Calvin on preaching. Ongepubliseerde lesing gehou tydens die Internasionale Calvyn Kongres.

WOLMARANS, JLP ea 1987. Van lessenaar na preekstoel AuckJandpark: Woordmeesters. 